\title{
IDENTIFIKASI FUNGSI PARIT-PARIT KUNO DI PROVINSI LAMPUNG
}

\author{
(The Identification of the Purpose of Old Moats in Lampung Province)
}

${ }^{1}$ Rusyanti, ${ }^{2}$ Muhammad Suwongso Sadewo, dan ${ }^{3}$ Nanang Saptono

${ }^{1,3}$ Balai Arkeologi Jawa Barat

Jalan Raya Cinunuk KM. 17 Cileunyi, Kabupaten Bandung

${ }^{2}$ Mahasiswa Program Pascasarjana Fakultas Ilmu Kebumian, Institut Teknologi Bandung (ITB) Jalan Ganesa No.10 Kota Bandung

Pos-el: rusyanti08@,gmail.com

\begin{tabular}{|c|c|}
\hline INFO ARTIKEL & $A B S T R A C T$ \\
\hline $\begin{array}{l}\text { Histori Artikel } \\
\text { Diterima : } \\
\text { Direvisi : } \\
\text { Disetujui : November } 2020\end{array}$ & $\begin{array}{l}\text { Moats or trenches are features that have been found since the } \\
\text { past and have local and contextual purposes. Archaeological } \\
\text { research of the West Java Center for Archaeology for two }\end{array}$ \\
\hline $\begin{array}{l}\text { Keywords: } \\
\text { Lampung, moat, } \\
\text { archaeology, subsistence }\end{array}$ & $\begin{array}{l}\text { archaeological remains from the } 7 \text { th century AD to the 20th } \\
\text { century AD. The purpose of the moats has long been a question } \\
\text { and has not been decided clearly. This desk study research } \\
\text { aimed to examine the purpose of the moats through descriptive } \\
\text { analvtic methods from the previous research that has been done. }\end{array}$ \\
\hline $\begin{array}{l}\text { Kata kunci: } \\
\text { Lampung, parit, } \\
\text { arkeologi, subsistensi }\end{array}$ & $\begin{array}{l}\text { The results provide a different overview of the purpose of the } \\
\text { moats in highland and lowland. Moats in highlands serve as a } \\
\text { source of water while in the lowlands it serves as flood } \\
\text { mitigation and local subsistence. Both results have given a } \\
\text { clear different purpose of the moats which strongly engaged } \\
\text { with their geological and local subsistence. }\end{array}$ \\
\hline
\end{tabular}

\begin{abstract}
ABSTRAK
Parit merupakan fitur yang telah ditemukan sejak masa lampau dan memiliki fungsi yang bersifat lokal dan kontekstual. Penelitian arkeologi Balai Arkeologi Jawa Barat selama dua dasawarsa telah menemukan 35 situs berparit yang berkonteks dengan tinggalan arkeologi dari abad ke-7 Masehi sampai abad ke-20 Masehi. Fungsi parit-parit tersebut lama menjadi pertanyaan dan belum diputuskan dengan jelas. Tulisan ini merupakan hasil penelitian desk study yang dilakukan melalui metode deskriptif analitik terhadap hasil penelitian sebelumnya yang telah dilakukan. Hasil penelitian memberikan gambaran fungsi parit yang berbeda antara parit di dataran tinggi dan parit di datarn rendah. Parit di dataran tinggi berfungsi sebagai sumber mataair sedangkan parit di dataran rendah berfungsi sebagai parit sebagai mitigasi banjir dan subsistensi lokal. Kedua fungsi tersebut memberikan batasan fungsi parit yang sangat kontekstual dan memiliki relasi yang kuat dengan kondisi geologi dan budaya subsistensi setempat.
\end{abstract}


PENDAHULUAN

Lampung merupakan kawasan di ujung Pulau Sumatera yang menyimpan banyak tinggalan arkeologis yang masih dieksplorasi hingga kini. Lampung terbagi menjadi dua bentukan alam yang kontras, yaitu wilayah dataran tingi di atas $>500$ mdpl di yang dilalui wilayah sungai (WS) Semangka dan wilayah dataran rendah yang menunjam pada ketinggian $<50-500$ mdpl yang dilalui wilayah sungai (WS) SeputihSekampung dan WS MesujiTulangbawang (Wiryawan, et al. 1999).

WS Semangka termasuk ke dalam Taman Nasional Bukit Barisan Selatan (TNBBS). Way Semangka memiliki posisi sejajar dengan patahan (sesar) Semangko-Kumering, yaitu bagian dari sesar Sumatera yang menjadi tanda wilayah ini dipengaruhi oleh kontrol tektonik (van Bemmelen 1949; Supartoyo, Surono, dan Putranto 2014; Sieh dan Natawidjaja 2000; Aribowo 2016).

WS Seputih-Sekampung dan WS Mesuji-Tulangbawang, berada di bagian tengah Lampung dominan berupa dataran rendah, rawa-rawa, dataran alluvial, pasang-surut, dan river basin. (Gambar 1).
Wilayah Lampung telah dieksplorasi oleh Balai Arkeologi Bandung sejak tahun 1994. Selama rentang penelitian dari tahun 1994 hingga 2018 telah ditemukan situs-situs arkeologi yang diindikasi sebagai perrmukiman kuno di tiga wilayah sungai (WS), yaitu WS Way Sekampung, WS Way SeputihSekampung, dan WS MesujiTulangbawang (Gambar 1).

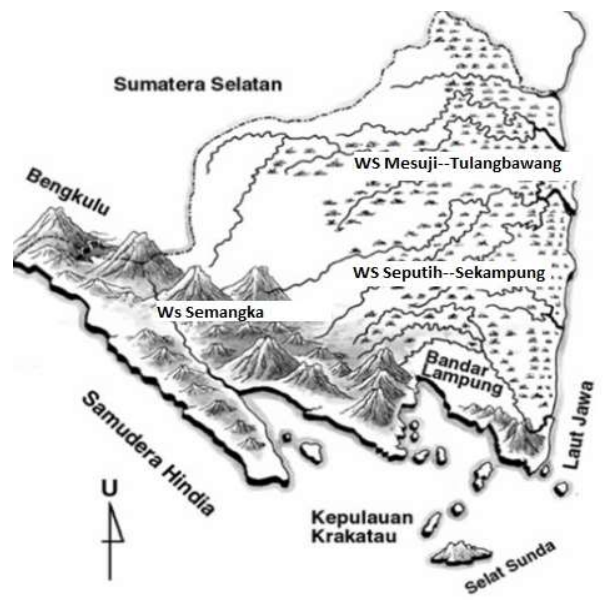

Gambar 1 Relief Lampung; Pegunungan di bagian barat (WS Semangka) dan dataran rendah rawa-rawa di bagian utara dan tengah (WS Mesuji-Tulangbawang), dan bagian selatan (WS SeputihSekampung) (Sumber: Wiryawan et al. 1999) dengan penyesuaian.

Karakteristik situs permukiman yang ditemukan pada umumnya berupa situs berparit di tepi sungai dengan temuan penyerta berupa fragmen keramik dan tembikar. Pada beberapa situs ditemukan juga prasasti dan tinggalan tradisi megalitik berupa menhir, dolmen, batu 
datar, dan batu bergores (Laili, 2005; Laili 2014; Saptono 2014).

Kronologi situs-situs berparit di Lampung didapat dari beberapa sumber penanggalan, yaitu prasasti dari abad ke-7 Masehi (Palas Pasemah) sampai dengan ke-14 M (Hujung Langit, Tanjung Raya, dan Batara Guru Tuha) (Utomo 2007; Damais 1995; Tobing 2004); penanggalan relatif keramik dari abad ke-10-20 M (Saptono 2003; Eriawati 2004; Triwurjani 2011; Rusyanti et al. 2018; Rusyanti et al. 2019); dan data sejarah dari abad ke-5 M, yaitu berita Cina dari Dinasti Liang, yang menyebutkan To-lang P'o-hwang, suatu kerajaan yang berada di aliran Sungai Tulangbawang (Poesponegoro dan Notosusanto 1993), serta sebutan Tulimbavam (Tulangbawang) dan Cacampom (Sekampung) pada abad ke16 M dalam Suma Oriental karya Tomé Pires (Cortesao 2018).

Terdapat sepuluh situs berparit di WS Semangka, sepuluh di WS Mesuji-Tulangbawang, dan 15 di WS Seputih-Sekampung sehingga total terdapat 35 situs berparit. 82 Situs berparit pernah menjadi perbincangan di Nam Mun Valley, Thailand pada tahun 1940an yang diduga berasal dari periode neolitik. Penelitian tersebut masih belum tuntas dan fungsi parit masih belum jelas. Lokasi parit disinggung berdekatan dengan paleochannel dan tampaknya dipengaruhi oleh pergerakan yang bersifat struktural yang berkorelasi dengan sesar (Dougald J.W dan Scott 2015; Rusyanti, Saptono, dan Widyastuti, 2020).

Rusyanti et al (2020) dengan mengacu pada rute migrasi jalur barat Austronesia (Simanjuntak 2017) menduga bahwa perilaku membuat parit yang ada di Lampung dapat dikaitkan dengan diaspora Austronesia jalur barat yang melewati wilayah Thailand sebelum masuk ke nusantara. Temuan perantara situs-situs Austronesia di wilayah Sumatera telah ditemukan di Aceh dan Sumatera bagian utara dan selatan, meskipun tidak disebut sebagai situs berparit, seperti Situs Loyang Mandale (Wiradnyana 2015; 2012) dan Situs Gua Harimau di Ogan Komering Ulu Selatan yang berbatasan dengan Danau Ranau, Lampung (Simanjuntak et al. 2017; Fauzi and Simanjuntak 2016). Selain memunculkan dugaan bahwa perilaku membuat parit adalah aktivitas yang sama yang dilakukan oleh pendukung Austronesia, dugaan lain 
yang masih menjadi permasalahan sebagaimana permasalahan di Nam Mun Valley adalah apa fungsi dari parit-parit tersebut.

Beberapa diskusi menyebut fungsi parit dibuat sebagai pengaman banjir dan binatang buas, namun asumsi tersebut masih belum tuntas dibuktikan dengan spesifik (Rusyanti, Saptono, Widyastuti, 2020).

Parit (Inggris: trench, ditch, drain, moat, channel, watercourse, conduit, duct, tunnels) menurut Cambridge Dictionary adalah saluran terbuka yang digali pada tanah dengan fungsi pada umumnya untuk menyalurkan air atau membagi lahan. Fungsi parit-parit menurut Bennet Bronson (1967) dalam konteks masa lampau maupun masa kini umumnya berkaitan dengan kepentingan tempat tinggal daripada kebutuhan untuk upacara, sedangkan menurut Naniek Harkantiningsih (1999) parit berfungsi sebagai perlindungan diri dari gangguan alam dan manusia (Bronson dan Harkantiningsih dalam Triwurjani 2011:6). Umumnya fungsi tersebut dapat dieksplisitkan sesuai dengan konteksnya masing-masing dengan melakukan berbagai analisis dan pendekatan yang relevan.
Mengacu pada permasalahan tersebut di atas, penelitian mengenai parit penting untuk dilakukan mengingat sifatnya yang kontekstual. Sumber literatur tentang objek ini juga sangat terbatas. Selain itu, parit merupakan bentukan fitur yang rentan rusak sehingga tujuan penelitian ini adalah selain melakukan update keberadaan parit dalam konteks dokumentasi akademis, juga berupaya mendapatkan alasan yang logis dan spesifik mengenai fungsi parit-parit kuno yang ada di Lampung. Hasil penelitian ini selanjutnya dapat menjadi rujukan dalam melakukan penelitian lanjutan atau sejenis, pendalaman, dan pengembangannya di masa yang akan datang.

\section{METODE}

Tulisan ini merupakan hasil penelitian desk study yang dilakukan dengan pendekatan review dan verifikasi terhadap hasil penelitian yang telah dilakukan sebelumnya dalam kurun waktu tahun 1994-2018. Objek yang disasar adalah situs-situs berparit di Propinsi Lampung. Review dan verifikasi meliputi pembacaan ulang, klasifikasi, pemetaan ulang, dan kontekstualisasi data dengan sumbersumber lain yang relevan. Simpulan 
merupakan hasil review berupa alasan logis mengenai fungsi parit yang lebih spesifik dan kontekstual.

\section{HASIL DAN PEMBAHASAN}

\section{Fungsi parit dalam berbagai literatur}

Penelitian mengenai parit di Indonesia sejauh ini ditemukan pada empat sumber literatur di luar Lampung, yaitu di Kalimantan, Riau, Komering Ulu, dan Jawa Barat.

Parit di Kalimantan ditemukan di Situs Kuta Bataguh (5-19 M), Kuala Kapuas, Kalimantan Tengah. Parit berupa kanal dengan lebar $5 \mathrm{~m}$ dan tertutup lapisan gambut sedalam $50 \mathrm{~cm}$ berfungsi sebagai pembatas lahan dan pertahanan (Sunarningsih, Hartatik, dan Yogi 2020)

Parit di Riau ditemukan di Situs Padang Candi, Kuantan Singingi. Bentukan lahan yang menyerupai parit (trench-like morphology) tersebut berukuran panjang $62 \mathrm{~m}$ berada di dataran rendah alluvial berdekatan dengan lokasi permukiman kuno dan Sungai Batanghari. Fungsi parit ini masih menyisakan pertanyaan apakah sebagai lahan pertanian ataukah kolam buatan yang berfungsi simbolis sebagai tempat dewa-dewa (Arief, 2019).
Penelusuran studi pustaka di Balai Arkeologi Sumatera Utara belum menjumpai karakteristik situs berparit sejenis seperti di Lampung. Parit di wilayah kerja Balai Arkeologi Sumatera Selatan baru ditemukan satu literatur dan tidak disertai gambar. Parit ditemukan di Situs Padang Ratu, Kawasan Danau Ranau, Ogan Komering Ulu, yang secara administratif berbatasan dengan Kabupaten Lampung Barat terdapat permukiman lama di atas bukit yang dibatasi dengan siring (parit) yang pada masa lampau dijadikan sarana transportasi antar dusun dengan menggunakan kuda. Kondisi siring saat ini berisi air yang dipergunakan penduduk untuk kebutuhan sehari-hari (Siregar, 2014).

Berbeda dengan di Sumatera, keberadaan parit di Jawa Barat telah disebut secara eksplisit dalam Prasasti Kawali IA, Ciamis (abad ke-14 M) dan dalam Prasasti Batu Tulis, Bogor (1533 M). Berikut kutipan Prasasti Kawali 1A:

“... nihan/tapak/wa lar nu siya muli ${ }^{\circ}$ a tapa $(k /)^{\circ}$ na pa ${ }^{\circ}$ rbu raja was/tu Mayadêg/ di kuta kawa li nu mahayu na kadatu ${ }^{\circ}$ n/ surawisesa nu marigi sa kulilin dayoh nu najur sakala desa ${ }^{\circ}$ aya nu pa (n/) dori pakena 
gawe rahhayu pakon/hobol/ja

ya dina bu ana ((Djafar 1991a)

Terjemahan

“... Inilah tanda bekas beliau yang mulia Prabu Raja Wastu [yang] berkuasa di Kota Kawali, yang memperindah kedaton Surawisesa, yang membuat parit [di] sekeliling ibukota, yang memakmurkan seluruh desa. Semoga ada penerus yang melaksanakan berbuat kebajikan agar lama jaya di dunia..." (Djafar, 1991a; Nastiti 1996).

Tertulisnya kata 'parit' secara jelas pada prasasti Kawali 1A mendorong dilakukannya penelusuran secara arkeologis dan mengkonfirmasinya lebih lanjut pada penelitian tahun 2011, dalam konteks permasalahan melacak jejak permukiman di Kawali. Hasil penelitian menemukan bahwa di sebelah utara Astana Gede Kawali ditemukan fitur parit dengan kedalaman satu meter yang melintang barat-timur. Batas parit sebelah barat merupakan jalur irigasi yang terputus di lahan kosong sebelah timur. Di lahan ini ditemukan satu fragmen keramik dan dua fragmen tembikar. Di sebelah utara fitur parit ditemukan pula sisa kuta (pencut) (tembok/benteng). Sisa kuta sebelah timur masih terlihat berupa susunan batu dengan panjang $40 \mathrm{~m}$, tinggi 2,40 m, dan lebar 29 m. Belum diketahui dating absolut untuk kedua fitur (fitur parit dan kuta) tersebut apakah berkorelasi atau sezaman dengan keberadaan Prasasti Kawali. Test pit dilakukan di area situs tetapi tidak menjumpai sampel arang yang dapat dianalisis kronologinya (dating) (Rusyanti, 2011).

Situs Astana Gede sendiri merupakan hutan lindung yang berada di tepi Sungai Cibulan, dan dilintasi aliran Sungai Cikadondong dan Cigarunggang, serta terdapat parit yang mengarah ke Sungai Cimuntur (Prijono, 1994/1995; Djafar, 1991; dan Nastiti, 1996 dalam Saptono, 2013). Sama halnya dengan isi dari Prasasti Kawali IA, hal senada ditemukan pada isi dari Prasasti Batutulis. Parit dalam prasasti ini disebut dengan kalimat:

“....nu nyusuk na pakwan .....”

yang artinya:

"...yang memariti di Pakuan..."

(Djafar 2011).

Prasasti Batutulis dikeluarkan

oleh Prabu Surawisesa untuk mengenang jasa ayahnya Sri Baduga Maharaja ketika memerintah kerajaan Sunda (Djafar, 1991; Djafar, 2011; Zahorka, 2007). Agustijato Indradjaya berpendapat bahwa makna parit dalam konteks prasasti tersebut dapat bermakna ganda, yaitu baik dalam arti 
membuat (bangunan) parit yang sebenarnya yang didukung oleh keterangan Bujangga Manik, Abraham van Riebeeck (1704), dan Pleyte (1911) juga dapat bermakna yang lebih luas yaitu parit dalam arti memariti atau melindungi kerajaan dari ancaman luar dengan mengacu pada keterangan dari Carita Parahyangan (16 M) yang menyebutkan perlunya setia pada kebiasaan (adat), dan keaslian leluhur agar tidak mudah disisipi oleh musuh besar dan musuh kecil “... mana mo kadatangan ku musu (h) ganal, musu (h) alit..." yang artinya "karena tidak terdatangi oleh musuh kasar, musuh halus" (Atja dan Saleh Danasasmita, 1991 dalam Indradjaya 2000; Poesponegoro dan Notosusanto 2010).

Lalu bagaimana halnya dengan isi prasasti-prasasti yang ada di Lampung? Dari ketujuh prasasti yang ada, tidak ada satu pun yang menyebut tentang parit. Prasasti yang ada seperti Batara Gurun Tuha dan Prasasti Batu Bedil (14 Masehi) berisi tentang mantra suci yang berkaitan dengan agama Hindu dan Buddha, dan Prasasti Hujung Langit (10 Masehi) tentang sima (daerah perdikan bebas pajak), dan Prasasti Palas Pasemah (7 Masehi) tentang persumpahan dan kutukan agar patuh kepada Kedatuan Sriwijaya (Utomo, 2007).

Saat ini baru didapat satu data etnografi yang menggambarkan tentang deskripsi suatu perkampungan tradisional di Lampung yang berada di tepi sugai. Data etnografi tersebut tidak menyebut perihal parit. Perkampungan masyarakat Lampung disebut tiyuh, anek, atau pekon dengan ciri berada dekat dengan sungai. Sekitar kampung terdapat tempat beternak dan tempat mandi umum yang disebut dengan kuwaian. Satu kampung biasanya dihuni oleh satu keluarga besar. Satu kampung dibagi beberapa bagian yang disebut bilik, yaitu tempat kediaman suku dan di setiap bilik terdapat rumah besar yang disebut nuwou balak atau nuwou menyanak (Hadikusuma, 1977/1978 dalam Saptono, 2014).

Tidak disebutnya parit pada literatur etnografi permukiman masyarakat di Lampung turut meragukan asumsi mengenai fungsi parit yang dikaitkan sebagai pengaman dari binatang buas, di antaranya gajah. Meskipun gajah terkenal di Lampung tetapi peranannya dalam sejarah dan kebudayaan lebih banyak didokumentasikan di wilayah Aceh. Gajah di Aceh terkenal sebagai bagian 
armada perang. Perhatian tentang gajah meningkat di kalangan orang Eropa sejak Portugis sampai ke India, sehingga seorang pelaut terkenal, yaitu Vasco da Gama (abad ke-15 M), membuat catatan cara menangkap dan menjinakkan gajah serta cara gajah berperang. Perburuan gajah dilakukan dengan cara memberi racun pada makanan yang disukainya seperti pisang dan tebu (Koestoro, 2014).

Hikayat Aceh yang ditulis pada masa Sultan Iskandar Muda (16041637) menceritakan gajah yang dimilikinya sangat kuat dan berani. Oleh karena itu, kota tidak dibentengi dan berbeda dengan kota lain yang biasanya berbenteng. Hingga abad ke-17 M, gajah masih banyak dijumpai di hutan-hutan Aceh seperti tertulis dalam kitab Bustanu's-Salatin yang ditulis oleh ArRaniry. Gajah merupakan hewan yang dijinakkan oleh kesultanan sehingga keberadaannya tidak mengganggu lingkungan di dalam kota. Gajah didapati mengganggu ketika menemukan permukiman dalam lintasannya yang biasanya membentuk angka delapan. Penangkapan gajah oleh masyarakat Gayo (nondong gajah) menurut etnolog Snouck Hurgronje, dilakukan dengan cara melempar lembing dan memasang jerat (lelawah) pada jalur setapaknya.
Ketika gajah menginjak jerat, kayu atau bambu runcing akan mengenai tubuhnya. Alat tersebut disebut gedabohan, yaitu alat yang sama yang digunakan untuk membunuh badak. Belakangan penangkapan gajah kemudian juga menggunakan senjata api (Koestoro, 2014). Berdasarkan uraian tersebut, tampaknya parit di Lampung memiliki fungsi selain sebagai jebakan binatang buas.

Kondisi situs berparit di Lampung saat ini sebagian besar berupa kebun dan areal pertanian atau persawahan. Permukiman lamanya saat ini sudah banyak yang pindah mendekati jalan raya. Beberapa data mendapati situs-situs permukiman berparit seperti di hulu Way Seputih sudah sulit dikenali, karena sejak tahun 1985 lahan tersebut dijadikan persawahan (Saptono, 2014). Data yang sama bahwa banyak parit yang sudah tidak dapat dikenali didukung pula dari Balai Pengelolaan Daerah Alira Sungai (BPDAS) bahwa dominan tutupan lahan di Lampung saat ini difungsikan untuk permukiman dan olah lahan perkebunan (Balai Pengelolaan Daerah Aliran Sungai dan Hutan Lindung-Way Seputih Sekampung, 2010). Kondisi tersebut otomatis merupakan ancaman 
bagi keberadaan deposit arkeologi termasuk fitur parit-parit kunonya.

\section{Parit-parit Kuno di WS Semangka}

Situs berparit di WS Semangka berjumlah sepuluh situs (Tabel 1) di aliran Way Rubok (Gambar 2). Morfologi situs berupa parit sedalam dan selebar 20 - $40 \mathrm{~m}$, yang sebenarnya merupakan parit alami berupa lembah mata air bentukan sesar atau kolam sesar (sagpond). Penduduk setempat menyebutnya dengan siring. Mata air yang terbendung tersebut sebagian dimanfaatkan sebagai kolam ikan, dan yang membentuk rawa difungsikan sebagai sawah (Gambar 3). Namun demikian, parit ini sebagian besar lebih berfungsi sebagai sumber air karena tanah di lingkungan situs berupa tufa dari letusan Gunung api Ranau yang bersifat porous (cepat menyerap air), sehingga posisi air tanah menjadi sangat dalam (Rusyanti et al. 2020; Rusyanti, Purwoarminta, Krama, Widyastuti, Setiawidjaya, et al. 2018).

Sawah dan ikan yang dibudidayakan sebagian merupakan kegiatan sampingan karena mayoritas penduduk di sekitar situs berparit mengolah lahan untuk pertanian sayur dan perkebunan kopi. Kebutuhan air didapat dari siring-siring yang ada di bawahnya.

Kaitan fungsi parit sebagai pengaman dari binatang buas belum ditemukan

Tabel 1. Sepuluh situs berparit di WS

Semangka

\begin{tabular}{|l|l|}
\hline No. & Nama Situs \\
\hline 1. & Hujung Langit \\
\hline 2. & Tanjung Raya \\
\hline 3. & Batu Putih \\
\hline 4. & Pulau Pinang \\
\hline 5. & Punjung \\
\hline 6. & Negeri Ratu \\
\hline 7. & Puncak Ham Kebik \\
\hline 8. & Batu Raja \\
\hline 9. & Hujung Kampung Tuha \\
\hline 10. & Hujung Lamban Batin \\
\hline & Sumber: Rusyanti, Widyastuti, \\
\hline
\end{tabular}

Purwoarminta, dan Krama 2018; Rusyanti, et al. 2019b)

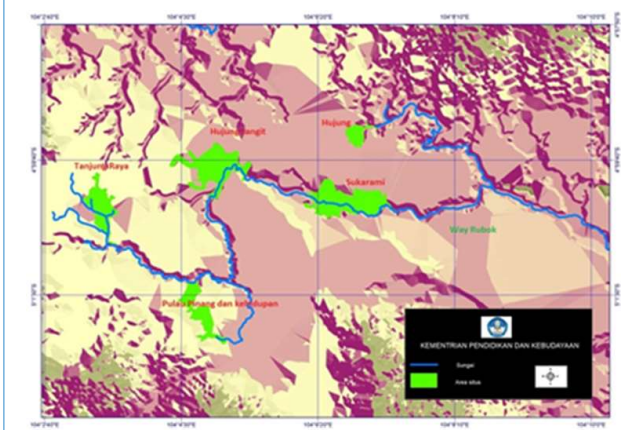

Gambar 2. Peta sebaran situs berparit di Way Rubok, Liwa Lampung Barat (Sumber: Rusyanti et al.2018)

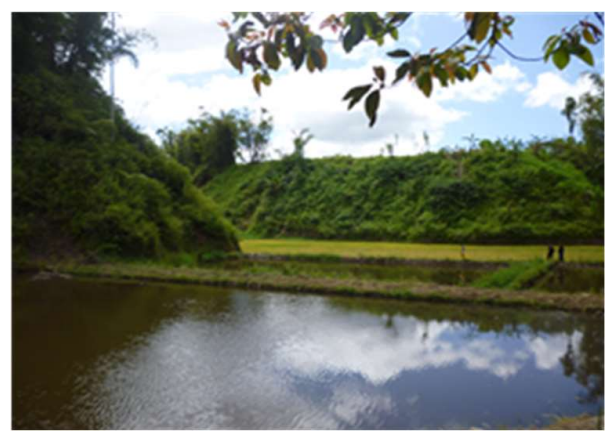

Gambar 3. Sagpond (kolam sesar) atau siring di Situs Tanjung Raya, Lampung Barat (Sumber: Rusyanti et al. 2012) 
dalam sumber literatur ataupun wawancara. Binatang yang mendiami lembah-lembah siring adalah beruk (Macaca nemestrina). Hewan ini mendiami habitatnya di siring dan seringakali merusak kebun petani. Cara mengusirnya adalah dengan membuat jebakan di lahan kebun berbentuk kandang dari rakitan kayu dan bambu, bukan di siring (Gambar 4).

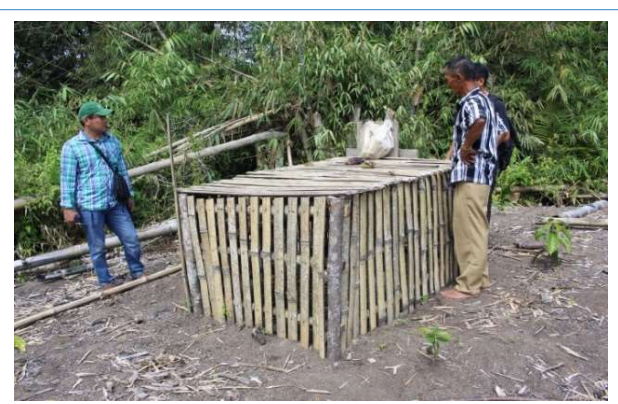

Gambar 4. Jebakan beruk di Situs Hujung Kampung Tuha. Rimbunan pohon bambu adalah siring alami, habitat beruk (Sumber: Rusyanti et al. 2018).

Parit-parit kuno di WS SeputihSekampungWS Way Seputih--

Sekampung mengalir melewati dua kabupaten, yaitu Kabupaten Lampung Tengah dan Kabupaten Lampung Selatan. WS tersebut meliputi empat wilayah daerah aliran sungai (DAS), yaitu Sekampung, Seputih, KambasJepara, dan Bandar LampungKalianda. Geologi wilayah ini terbentuk dari batuan Pra-Tersier (batuan malihan, sedimen, dan terobosan), batuan Tersier (batuan sedimen dan
Tabel 2. 15 Situs-situs berparit di WS Seputih-Sekampung

\begin{tabular}{|c|c|c|}
\hline No. & Situs & Kondisi parit \\
\hline 1. & $\begin{array}{l}\text { Keramat } \\
\text { Teluk }\end{array}$ & $\begin{array}{l}\text { Parit-parit menghubungkan } \\
\text { Way Pengubuhan dan rawa } \\
\text { yang mengering dengan } \\
\text { lebar } 20-100 \mathrm{~m}\end{array}$ \\
\hline 2. & $\begin{array}{l}\text { Gedong } \\
\text { Ratu }\end{array}$ & $\begin{array}{l}\text { Kelokan Way Pengubuhan; } \\
\text { kelokan ini sekarang sulit } \\
\text { dikenali 1985, karena sudah } \\
\text { berupa sawah }\end{array}$ \\
\hline 3. & $\begin{array}{l}\text { Tambah } \\
\text { Luhur }\end{array}$ & $\begin{array}{l}\text { Feature cekungan } \\
\text { memanjang dengan lebar } 2,5 \\
\mathrm{~m}\end{array}$ \\
\hline 4. & $\begin{array}{l}\text { Tanjung } \\
\text { Langit }\end{array}$ & $\begin{array}{l}\text { Fitur kanal di sebelah barat } \\
\text { daya situs menghubungkan } \\
\text { Way Pengubuhan dan Way } \\
\text { Karang Sio sejauh 100m. } \\
\text { Lebar kanal } 8 \mathrm{~m} \text { dan dalam } 4 \\
\text { m }\end{array}$ \\
\hline 5. & $\begin{array}{l}\text { Talang } \\
\text { Keramat }\end{array}$ & $\begin{array}{l}\text { Sudah menjadi } \text { sawah. } \\
\text { Terdapat makam keramat } \\
\text { dibatasi pohon jat }\end{array}$ \\
\hline 6. & $\begin{array}{l}\text { Pugung } \\
\text { Rahardjo }\end{array}$ & $\begin{array}{l}\text { Parit dan gundukan tanah } \\
\text { membentuk ruang-ruang } \\
\text { batas alam berupa sungai }\end{array}$ \\
\hline 7. & Gelombang & $\begin{array}{l}\text { Parit selebar 2-3 meter, } \\
\text { dengan kedalaman 1,2-2 m, } \\
\text { membentuk tiga ruang. }\end{array}$ \\
\hline 8. & $\begin{array}{l}\text { Benteng } \\
\text { Sari }\end{array}$ & $\begin{array}{l}\text { Wilayah desa dikelilingi } \\
\text { gundukan tanah dan parit } \\
\text { yang membagi ruang-ruang } \\
\text { sehingga } \\
\text { benteng. }\end{array}$ \\
\hline 9. & Periki & $\begin{array}{l}\text { Bentuk situs memiliki denah } \\
\text { segi empat dikelilingi } \\
\text { gundukan tanah }(5-7 \mathrm{~m}) \text { dan } \\
\text { parit }(2-4 \mathrm{~m})\end{array}$ \\
\hline 10. & Gedig & $\begin{array}{l}\text { Gundukan tanah dan parit } \\
\text { berbatasan langsung dengan } \\
\text { rawa dan } \\
\text { Sekampung, }\end{array}$ \\
\hline 11. & Meris & $\begin{array}{l}\text { Benteng tanah duikelilingi } \\
\text { parit }\end{array}$ \\
\hline 12. & Cicilik & $\begin{array}{l}\text { Parit yang digali berbatasan } \\
\text { dengan rawa }\end{array}$ \\
\hline 13. & Pejambon & $\begin{array}{lr}\text { Parit } & \text { barat-timur } \\
\text { menghubung-kan } & \text { dengan } \\
\text { aliran Sekampung } & \end{array}$ \\
\hline 14. & Jabung & $\begin{array}{l}\text { Benteng segi empat } \\
118 \times 150 \mathrm{~m} \text {, terdiri dari parit } \\
\text { luar dan gundukan tanah di } \\
\text { bagian dalam }\end{array}$ \\
\hline 15. & Negarasaka & $\begin{array}{l}\text { Gundukan tanah di bagian } \\
\text { parit bagian luar dan berlapis } \\
\text { ke dalam }\end{array}$ \\
\hline
\end{tabular}

(Sumber: Prijono, 2014:79-88; Saptono, 2012:48-60; Saptono, 1995b:46; Prijono, 1994:47-49; Prijono, 1995:84-85;

Saptono 2014a:70-71; Triwurjani 2011:10-11, 44, 47, 48, 56, 58, 63); Widyastuti 2007:92; Laili, 2009:19-27; Saptono, 2007:73) 
gunung api), dan batuan Kuarter (batuan sedimen, gunungapi, dan endapan permukaan). Way Seputih dan Way Sekampung bersumber dari pegunungan Bukit Barisan di sebelah barat dengan ketinggian lebih dari 2000 mdpl, yang kemudian menurun tajam sampai dengan $50 \mathrm{mdpl}$ yang menandai dataran rendah yang sangat luas. Way Seputih dan Way Sekampung mengalir ke arah timur dan terbagi oleh Pegunungan Ulu Waisamang. Daerahdaerah yang menonjol di sekitar Way Jepara membelokkan masing-masing Way Seputih dan Way Sekampung ke arah utara dan selatan, yang kemudian membentuk delta-delta pantai. Salah satu delta yaitu Japara-Kambas membentuk WS yang lebih kecil dan terlihat terpisah. Tata guna lahan di wilayah ini didominasi pohon lebat dan tanaman hutan di dataran tinggi dan pegunungan hingga perbukitan dengan kelerengan yang sedang, padi dan tebu di dataran rendah, dan pertanian potong bakar (slash and burn) (Kementerian Pekerjaan Umum, 2010b). Situs-situs berparit di wilayah ini ditemukan sebanyak 15 lokasi (Tabel 2). Berbeda dengan WS Semangka, morfologi parit di WS Seputih-Sekampung memperlihatkan bentukan-bentukan yang sengaja dibuat, bukan bentukan alami oleh alam.

Triwurjani (2011) dalam bukunya Situs-situs Megalitik di DAS Sekampung telah menyertakan denah parit-parit yang mengelilingi situs-situs di WS Sekampung. Berdasarkan bentuk yang diamati, parit-parit di WS Sekampung ada yang berbentuk melingkar dan ada pula yang berbentuk persegi (Triwurjani, 2011) (Gambar 5). Dua denah lainnya didapat pula di Situs Tambah Luhur dan Kramat Teluk (Prijono, 2014). Analisis parit pada tulisan ini dilakukan dengan menggunakan Citra Landsat/Sentinel/Bing satellite/Google maps dengan melakukan pengamatan dan penggambaran profil ketinggian dan deskripsi variabel amatan situs ke dalam form isian (Gambar 6).

Tidak semua variabel ukuran didapatkan karena keterbatasan sumber data sekunder yang ada. Beberapa sumber hanya menyebut adanya keberadaan parit atau benteng tanah. Beberapa dengan ukuran, beberapa tidak disebutkan ukurannya. Hasil pengamatan citralandsat kemudian dipetakan dan dianalisis dengan mengacu peta geologi lembar Menggala Sheet 111(Burhan, Gunawan, and Noya 1993) dan peta geologi lembar Baturaja Sheet 1011 
(Gafoer, Amin T.C, and Pardede, 993),dengan resume hasil pada Tabel 3, Gambar 6, dan Gambar 7.

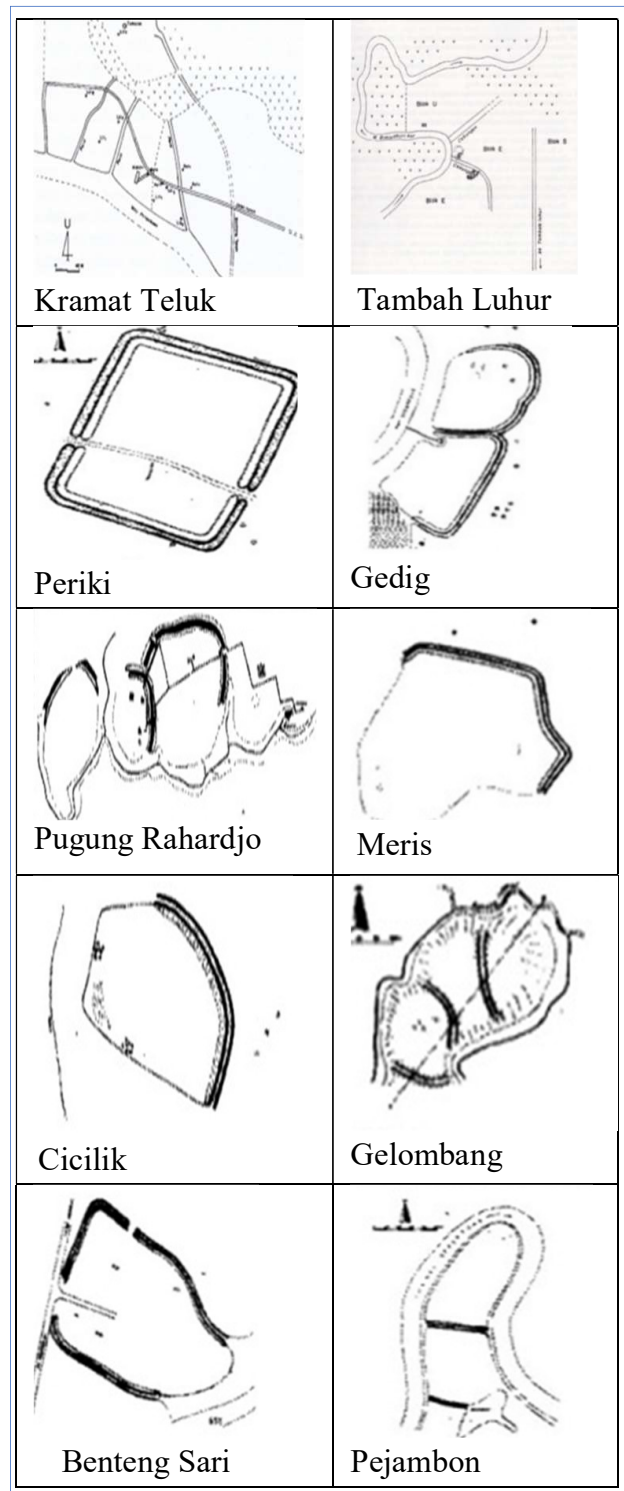

Gambar 5 Situs-situs berparit di WS Seputih-Sekampung (Sumber: Triwurjani, 2011; Prijono, 2014) 
Situs-situs pada DAS Seputih-Sekampung berada pada dataran yang sangat luas yang dipengaruhi oleh aktivitas sungai, dan di sebelah timur

Sungai Seputih merupakan sungai yang aktif karena perubahan bentuk badan sungai. Kelok sungai dan arah aliran dapat berubah dalam jangka waktu yang cukup dekat sehingga membentuk badan sungai yang baru yang merupakan kelanjutan dari badanbadan sungai yang lama. Bentuk lahan datar dengan aktivitas sungai aktif dapat mengakibatkan sebaran banjir yang cukup luas sehingga situs-situs yang terletak di DAS Mesuji ini sangat rentan dilanda banjir (Gambar 7a-b). Mayoritas situs-situs pada DAS SeputihSekampung tersebut di atas memiliki batas-batas berupa rendahan atau air di sekelilingnya, diduga kuat digunakan sebagai drainase atau saluran pembuangan air akibat banjir (Gambar 5 dan 7a-b) (Rusyanti et al. 2020).

\section{Parit-parit kuno di WS Mesuji-- Tulangbawang}

WS Mesuji--Tulangbawang terdiri dari dua DAS, yakni Mesuji dan Tulangbawang. Luas WS Mesuji-Tulang Bawang kurang lebih $16.625 \mathrm{~km}^{2}$. Kondisi geologi WS Mesuji-

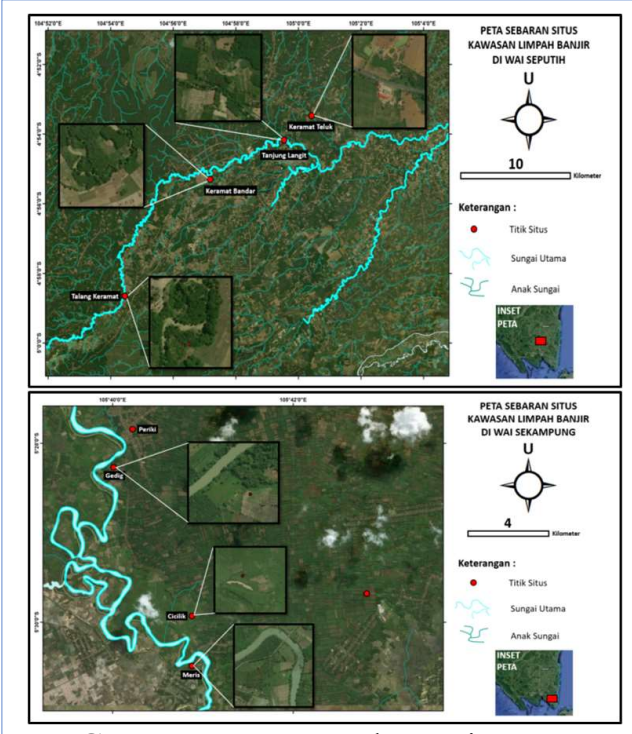

Gambar 7a-b. Peta sebaran situs WS Seputih dan Sekampung di daerah limpahan banjir (Sumber: Rusyanti et al. 2020)

Tulangbawang berdasarkan fisiografi terbagi menjadi empat satuan, yaitu Middle and Upper Palembang Beds, Andesites and Tuffs, Undeterentiated Sedimentary Tuffs, dan Lacrustrin Deposit of Way Lima Basin and Aludepol. Satuan Andesites and Tuffs dan Undeterentiated Sedimentary Tuffs menempati kawasan pegunungan dan perbukitan yang berada di hulu DAS Tulangbawang. Satuan Middle and Upper Palembang Beds dan Lacrustrin Deposit of Way Lima Basin and Aludepol menempati dataran rendah yang berada di DAS MesujiTulangbawang. Topografi DAS MesujiTulangbawang terbagi menjadi tiga kontur ketinggian, yaitu dataran rendah (<50 mdpl), perbukitan (50-500 mdpl), 
dan pegunungan $(>500 \quad$ mdpl;

Kementerian Pekerjaan Umum 2010a).

Situs-situs berparit di wilayah ini ditemukan di sepuluh lokasi (Tabel 4).

\begin{tabular}{|c|c|c|c|}
\hline No & Nama Situs & Fitur & Publikasi/Sumber \\
\hline 1 & $\begin{array}{l}\text { Benteng } \\
\text { Sabut }\end{array}$ & $\begin{array}{l}\text { Parit dan } \\
\text { gundukan tanah di } \\
\text { utara lebar } 2 \mathrm{~m} \\
\text { kedalaman } 1 \mathrm{~m} .50 \\
\text { m di selatan } \\
\text { terdapat lagi parit } \\
\text { berdenah segi } \\
\text { empat }\end{array}$ & $\begin{array}{l}\text { (Saptono 2014:72) } \\
\text { (Saptono 2002: } \\
86-101 \text { ) } \\
\text { (Saptono, 2010: } \\
\text { 5-16) }\end{array}$ \\
\hline 2 & $\begin{array}{l}\text { Keramat } \\
\text { Gemol }\end{array}$ & $\begin{array}{l}\text { Benteng dan parit } \\
\text { berdenah "U". } \\
\text { Lebar gundukan } \\
\text { tanah/benteng } 4 \mathrm{~m} \\
\text { ketinggian } 1-2 \mathrm{~m} \text {, } \\
\text { panjang } 80 \mathrm{~m} \text { dari } \\
\text { barat laut Way } \\
\text { kiri berakhir barat } \\
\text { daya Way Kiri. }\end{array}$ & $\begin{array}{l}\text { (Saptono 2014 73) } \\
\text { (Saptono, 2002: 86- } \\
\text { 101) } \\
\text { (Saptono, 2001: 26- } \\
46 \text { ) }\end{array}$ \\
\hline 3 & $\begin{array}{l}\text { Bakung } \\
\text { Udik I--III }\end{array}$ & $\begin{array}{l}\text { Benteng tanah } \\
\text { tinggi } 2 \mathrm{~m} \text { panjang } \\
10 \mathrm{~m} \text { dan parit } \\
\text { berupa cekungan } \\
\text { lebar } 6 \mathrm{~m} \\
\text { mengelilingi } \\
\text { kampung }\end{array}$ & (Saptono, 2014: 74) \\
\hline 4 & $\begin{array}{l}\text { Benteng } \\
\text { Prajurit } \\
\text { Putting- } \\
\text { gelang }\end{array}$ & $\begin{array}{l}\text { Fitur Benteng } \\
\text { membentang dari } \\
\text { Capang Turus ke } \\
\text { Barat laut } \\
\text { sepanjang } 95 \mathrm{~m} . \\
\text { Luas benteng } \\
1,625 \text { ha }\end{array}$ & $\begin{array}{l}\text { (Saptono, 2008: 49- } \\
-50 \text { ) } \\
\text { (Saptono, 2002: 86- } \\
-101 \text { ) }\end{array}$ \\
\hline 5 & $\begin{array}{l}\text { Tulung } \\
\text { Sawo }\end{array}$ & $\begin{array}{l}\text { Fitur Parit berupa } \\
\text { cekungan selebar } \\
1-1,5 \text { kedalaman } \\
0,5 \mathrm{~m}\end{array}$ & Saptono, 2008:55 \\
\hline 6 & $\begin{array}{l}\text { Canguk } \\
\text { Gaccak }\end{array}$ & $\begin{array}{l}\text { Parit dan benteng } \\
\text { tanah di bagian } \\
\text { timurmelintang } \\
\text { utara-selatan } \\
\text { menghubungkan } \\
\text { dua aliran sungai. } \\
\text { Artefak berupa } \\
\text { tinggalan } \\
\text { megalitik }\end{array}$ & (Saptono, 2007: 68) \\
\hline 7 & $\begin{array}{l}\text { Benteng } \\
\text { Minak } \\
\text { Temenggung }\end{array}$ & $\begin{array}{l}\text { Benteng utara- } \\
\text { selatan panang } \\
600-800 \text { m.Dua } \\
\text { gundukan } \\
\text { mengapit parit }\end{array}$ & (Saptono, 2007: 74) \\
\hline 8 & $\begin{array}{l}\text { Benteng } \\
\text { Majapahit }\end{array}$ & $\begin{array}{l}\text { Lahan terbagi 3, } \\
\text { megalitik, jenjang } \\
\text { tiyuh/anek }\end{array}$ & (Laili, 2007: 82) \\
\hline 9 & Batu Putih & $\begin{array}{l}\text { Permukiman } \\
\text { dekat sungai }\end{array}$ & (Saptono, 2004) \\
\hline 10 & $\begin{array}{l}\text { Gunung } \\
\text { Terang }\end{array}$ & $\begin{array}{l}\text { Pindahan Gunung } \\
\text { Putih }\end{array}$ & (Saptono, 2004) \\
\hline
\end{tabular}

Enam denah lama terkumpul

(Gambar 8), dengan form contoh isian situs (Gambar 9) dan resume hasil analisisnya pada Tabel 5, Gambar 9, dan Gambar 10.

Luas wilayah Mesuji-Tulangbawang $80 \%$ didominasi pertanian lahan kering, perkebunan, dan hutan tanaman produksi dengan ancaman erosi, sedimentasi, dan banjir terutama di pertemuan Way Sesah- Way Rarem, Way Abung-Way Sabuk - Way Rarem, Way UmbarWay Nakau-Way Rarem, Way Kanan di Kertajaya, Iling-Iling, Tebing Suluh dan Gunung Terang, dan di Way Pidada di Mesuji.

Analisis di WS MesujiTulangbawang sama dengan analisis di WS Seputih-Semangka. Beberapa situs tidak ditemukan denah lama sehingga pengamatan bertumpu pada lokasi koordinat yang terkadang menampilkan bentukan lahan yang terlihat berbeda dengan deskripsi situs berparit yang dekat dengan sungai. Beberapa situs tampak jauh dari sungai dan sulit mengenali bentukan parit sehingga membutuhkan beberapa kali pengecekan ulang.

Berdasarkan posisi geografisnya, Situs-situs di DAS Mesuji berada pada dataran yang sangat luas yang dipengaruhi oleh aktivitas sungai dan di sebelah timur sebagian dipengaruhi oleh aktivitas rawa yang berbatasan dengan 


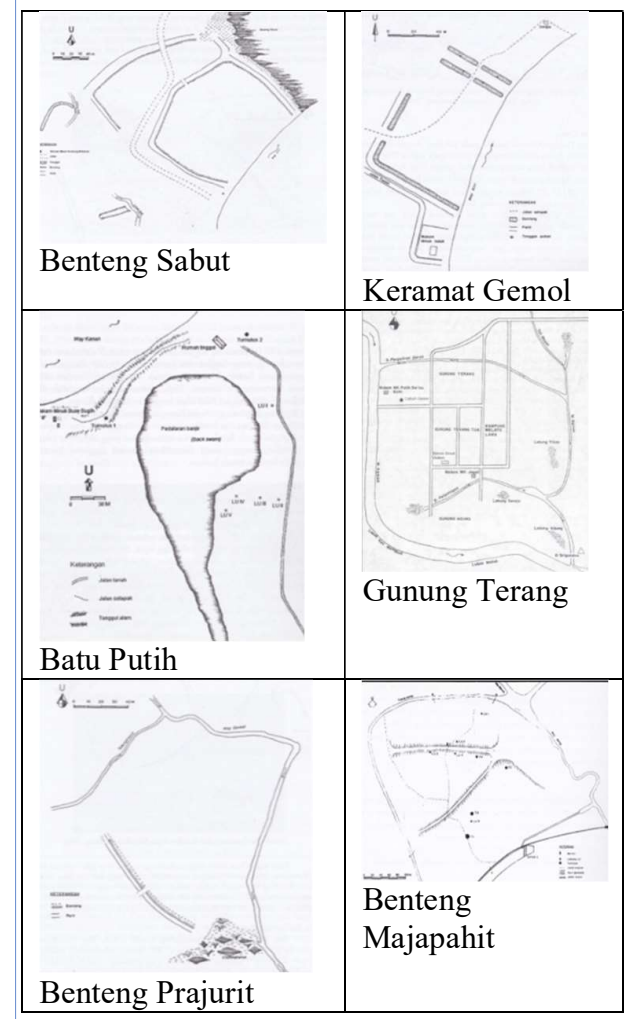

Gambar 8. Enam denah lama situs-situs di WS Mesuji Tulangbawang (Sumber: Laili 2007; Saptono 2001; Saptono 2002; Saptono, 2003; Saptono, 2004)

pantai, dan rawan banjir (Tabel 5).

Berdasarkan peta geologi lembar Menggala sheet 1111 (Burhan, Gunawan, and Noya 1993) mayoritas lokasi situs berada pada batuan berumur muda dengan komposisi batuan endapan sungai dan rombakan gunung api. Lapukan dari batuan tersebut menghasilkan tanah yang sangat baik sebagai bahan untuk pembuatan tembikar.

Sungai Mesuji merupakan sungai yang aktif karena perubahan bentuk

\begin{tabular}{|c|c|c|c|c|}
\hline No & Situs & $\begin{array}{l}\begin{array}{l}\text { Ukuran } \\
\text { parit } \\
\text { (meter/ } \\
\text { m) }\end{array} \\
\end{array}$ & $\begin{array}{l}\text { Jarak ke } \\
\text { sungai } \\
\text { (m) }\end{array}$ & $\begin{array}{l}\text { Ketinggian } \\
\text { situs }(\mathrm{m})\end{array}$ \\
\hline 1 & $\begin{array}{l}\text { Benteng } \\
\text { Sabut }\end{array}$ & $\begin{array}{l}\text { L: } 2, \mathrm{D}: \\
1\end{array}$ & $200 \mathrm{~m}$ & $0.5-2 \mathrm{~m}$ \\
\hline 2 & $\begin{array}{l}\text { Keramat } \\
\text { Gemol }\end{array}$ & $\begin{array}{l}\text { P: } 80 \mathrm{~m}, \\
\mathrm{~L}: 4, \mathrm{~T}: \\
1-2 \mathrm{~m}\end{array}$ & $20 \mathrm{~m}$ & $1 \mathrm{~m}$ \\
\hline 3 & $\begin{array}{l}\text { Bakung } \\
\text { Udik I-III }\end{array}$ & $\begin{array}{l}\text { P: 10, L: } \\
6, T: 2\end{array}$ & $200 \mathrm{~m}$ & $2 \mathrm{~m}$ \\
\hline 4 & $\begin{array}{l}\text { Benteng } \\
\text { Prajurit }\end{array}$ & P: $95 \mathrm{~m}$ & $50 \mathrm{~m}$ & $\begin{array}{l}\text { Tidak ada } \\
\text { denah } \\
\text { lama, } \\
\text { sebagai } \\
\text { pembandin } \\
\text { g, lokasi } \\
\text { sulit } \\
\text { dideskripsi }\end{array}$ \\
\hline 5 & $\begin{array}{l}\text { Tulung } \\
\text { Sawo }\end{array}$ & $\begin{array}{l}\text { L: } 1- \\
1,5, \mathrm{D}: \\
0,5\end{array}$ & $150 \mathrm{~m}$ & $\begin{array}{l}\text { Sulit } \\
\text { dideskripsi }\end{array}$ \\
\hline 6 & $\begin{array}{l}\text { Minak } \\
\text { Temenggung }\end{array}$ & $\begin{array}{l}\text { P: } 600- \\
800 \mathrm{~m}\end{array}$ & $\begin{array}{l}\text { Koordin } \\
\text { at tidak } \\
\text { diketahu } \\
\mathrm{i}\end{array}$ & $\begin{array}{l}\text { Sulit } \\
\text { dideskripsi }\end{array}$ \\
\hline 7 & Batu Putih & $\begin{array}{l}\text { Tidak } \\
\text { berparit, } \\
\text { lokasi di } \\
\text { limpahan } \\
\text { banjir, } \\
\text { terdapat } \\
\text { artefak } \\
\text { tembikar }\end{array}$ & $10 \mathrm{~m}$ & $2 \mathrm{~m}$ \\
\hline 8 & $\begin{array}{l}\text { Gunung } \\
\text { Terang }\end{array}$ & $\begin{array}{l}\text { Tidak } \\
\text { disebut }\end{array}$ & $700 \mathrm{~m}$ & $\begin{array}{l}\begin{array}{l}\text { Sulit } \\
\text { dideskripsi }\end{array}\end{array}$ \\
\hline 9 & $\begin{array}{l}\text { Benteng } \\
\text { Majapahit }\end{array}$ & $\begin{array}{l}\text { Tidak } \\
\text { disebut }\end{array}$ & $350 \mathrm{~m}$ & $\begin{array}{l}\text { Sulit } \\
\text { dideskripsi }\end{array}$ \\
\hline 10 & $\begin{array}{l}\text { Gunung } \\
\text { Tapa }\end{array}$ & $\begin{array}{l}\text { Tidak } \\
\text { disebut }\end{array}$ & $250 \mathrm{~m}$ & $\begin{array}{l}\text { Sulit } \\
\text { dideskripsi }\end{array}$ \\
\hline \multicolumn{5}{|c|}{ (Sumber: Rusyanti et al. 2020) } \\
\hline
\end{tabular}

badan sungai, kelok sungai dan arah aliran dapat berubah dalam jangka waktu yang cukup dekat, hal itu dapat terlihat dari perbandingan penelitian pada situs Benteng Prajurit Puting Gelang, di mana bentuk kelok sungai terlihat dengan jelas. Perubahan tersebut dapat terjadi akibat arus sungai yang terus menggerus badan sungai secara periodik ataupun aktivitas banjir pada saat musim penghujan tiba, mengakibatkan sebaran banjir yang cukup luas sehingga situssitus yang terletak di DAS Mesuji ini 


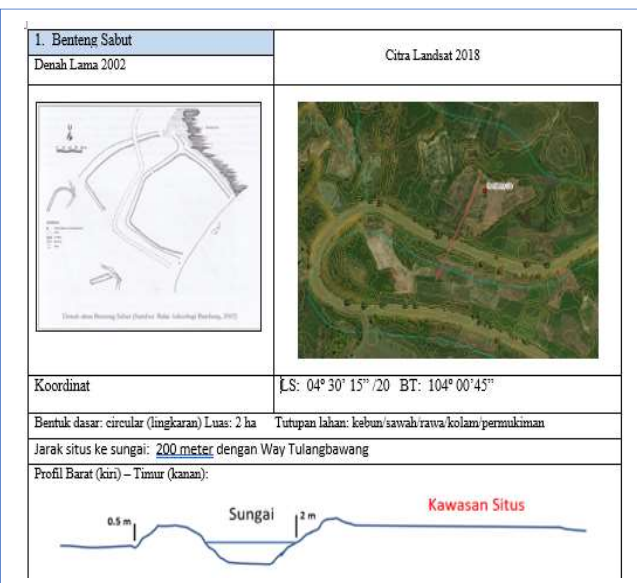

Gambar 9 Contoh form isian analisis di Situs Benteng Sabut (Sumber: Rusyanti et al. 2020)

sangat rentan dilanda banjir (Gambar $10)$.

Selain ancaman banjir yang berkaitan dengan mitigasi, terdapat data menarik yang berkaitan fungsi lain parit di WS Seputih-Sekampung dan WS Mesuji-Tulangbawang.

Pada situs seperti Keramat Teluk dan Benteng Sabut (Gambar 10), posisi parit justru cenderung sejajar dengan ketinggian sungai sehingga tampak adanya unsur kesengajaan pembuatan parit yang tidak selalu berkaitan untuk mengantisipasi banjir.

Parit-parit yang mengelilingi situs merupakan tempat kerbau air atau kerbau rawa (Bubalus bubalis atau Bubalis bubalis carabauesis) berkubang. Kerbau tersebut sengaja dibudidayakan untuk membajak sawah. Selain itu, ada juga pemanfaatan lain pembuatan parit-

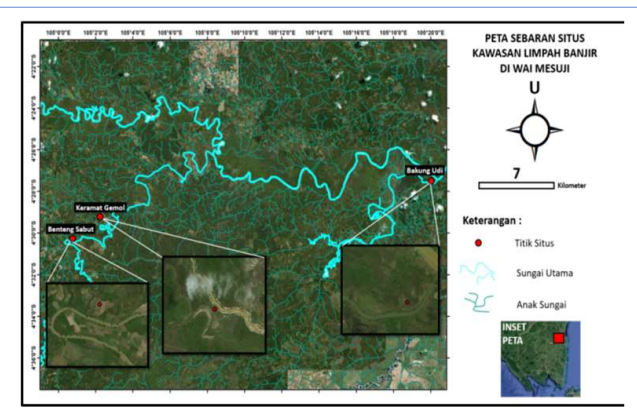

Gambar 10 Peta sebaran situs WS Mesuji-Tulangbawang di daerah limpahan banjir (Sumber: Rusyanti et al. 2020)

parit di dataran rendah Lampung, yaitu sebagai lebak lebung atau kolam budidaya ikan (Saptono, 2010).

Parit-parit yang dibuat mengelilingi sengaja dibentuk demikian sebagai jalur ikan dari dari dan ke sungai baik pada musim kering maupun musim banjir sehingga jalur tersebut merupakan rute habitatnya. Dengan demikian, petani tidak akan kehilangan ikan karena dibudidayakan dengan cara membuat parit sebagai mobilisasi lokal ikan-ikan.

\section{PENUTUP}

Situs-situs berparit di WS Semangka, WS Seputih-Sekampung dan WS Mesuji-Tulangbawang memperlihatkan fungsi parit yang erat kaitannya dengan kondisi morfologi dan geologi lingkugannya. Fungsi parit di WS Semangka yang lokasinnya di dataran tinggi (> $500 \mathrm{mdpl}$ ) merupakan kolam bentukan sesar (sagpond) sebagai sumber mata air utama. Tanah di Liwa 
merupakan limpahan tufa hasil erupsi Gunung api Ranau yang meresapkan air dengan cepat dan dalam. Pembuatan sumur dalam konteks ini lebih sulit daripada langsung mengambil dari mata air yang telah tersedia di sekitarnya.

Pemanfaatan kolam ikan dan sawah merupakan fungsi lain parit selain mitigasi. Fungsi parit di WS SeputihSekampung dan WS Mesuji dan Tulangbawang, erat kaitannya sebagai pengendali banjir mengingat $80 \%$ wilayah ini berada di dataran rendah limpahan banjir (<50 mdpl), serta lokasi dan ketinggiannya yang dekat sungai. Budidaya sawah dan ikan (lebak lebung) merupakan fungsi subsistensi terutama terlihat di Situs Benteng Sabut dan diduga pernah dipraktikkan juga di situssitus lainnya di WS Sekampung, terutama situs dengan morfologi ketinggian dengan sungai relatif sejajar. Fungsi parit sebagai pengaman dari ancaman binatang buas, baik harimau, gajah, maupun beruk tidak menguat pembuktiannya dalam desk study ini karena cara menangkap hewan tersebut tidak menggunakan parit.

\section{Saran dan Rekomendasi}

Penelitian ini merupakan desk study yang menggunakan data sekunder. Pengamatan citralandsat dilakukan berdasarkan lokasi koordinat yang ada. Perubahan morfologi situs saat ini sangat mungkin terjadi karena telah melalui rentang jarak dan waktu yang panjang sebelum diobservasi oleh peneliti. Pengecekan kembali di lapangan sangat diperlukan untuk memeriksa kembali kondisi parit-parit tersebut sekaligus pergeseran fungsi dan maknanya yang mungkin juga telah berubah. 


\section{DAFTAR PUSTAKA}

Aribowo, S. 2016. “Arsitektur Sesar Aktif Segmen Kumering di Antara Danau Ranau Hingga Lembah Suoh Sumatera Bagian Selatan.” Universitas Padjajaran Bandung.

Arief, Johan. 2019. “Geomorphological Identification at Padang Candi Site Kuantan Singingi Regency Riau Province." Purbawidya: Jurnal Penelitian Dan Pengembangan Arkeologi 8 (1) (June): 43-54.

van Bemmelen, R.W. 1949. The Geology of Indonesia Vol.IA. The Hague Netherlands: Martinus Nyhoff.

Balai Pengelolaan Daerah Aliran Sungai dan Huta Lindung-Way Seputih Sekampung (BPDAS-HL WSS). 2010. "Karakteristik DAS Way Semangka Dan Semangka DS Laporan Penelitian Balai Pengelolaan Daerah Aliran Sungai Way Sekampung Seputih.” BPDASHL-WSS: Bandar Lampung.

Burhan, W. Gunawan, dan Y. Noya. 1993. "Peta Geologi Lembar Menggala, Sumatera. Skala 1: 100.000. Sheet 1111." Bandung: Pusat Penelitian dan Pengembangan Geologi.

Cortesao, Armando. 2018. Suma Oriental Karya Tome Pires: Perjalanan Dari Laut Merah Ke Cina Dan Buku Francisco Rodrigues. Editor Armando Cortesao. Yogyakarta: Penerbit Ombak.

Damais, Louis Charles. 1995. Epigrafi Dan Sejarah Nusantara Pilihan Karangan LouisCharles Damais. Jakarta: Pusat Penelitian dan Dokumentasi Ecole Francais de Extreme Orient (EFEO): Jakarta.

Djafar, Hasan. 1991. "Prasasti-Prasasti Dari Masa Kerajaan Sunda." Makalah Seminar Nasional Sastra dan Sejarah Pakuan Pajajaran. Bogor. Universitas Pakuan.

—. 2011. "Prasasti Batu Tulis Bogor." Amerta Jurnal Penelitian Dan Pengembangan Arkeologi 29 No.1 (Juni): 1--13.

O’Reilly, D. J.W., dan Glen Scott. 2015. "Moated Sites of the Iron Age in the Mun River Valley, Thailand: New Discoveries Using Google Earth.” Archaeological Research

in Asia 3 (July): 9--18. (https://doi.org/https://doi.org/10.1016/j.ara.2015.06.001). Diakses 15 November 2020.

Eriawati, Yusmaini. 2004. "Tembikar Dan Keramik Cina di Situs Komplek Megalitik Batu Berak Dan Batu Tameng Lampung Barat.” dalam Teknologi Dan Religi Dalam 
Perspektif Arkeologi, editor Agus Aris Munandar, 22--41. Bandung: Ikatan Ahli Arkeologi Indonesia Komisariat Daerah Jawa Barat dan Banten.

Fauzi, Ruly dan Truman Simanjuntak. 2016. Harimau Cave and the Long Journey of Ogan Komering Ulu Civilization. Editor Truman Simanjuntak. Yogyakarta: Gadjah Mada University Press.

Gafoer, S., Amin T.C, dan R. Pardede. 1993. "Peta Geologi Lembar Baturaja, Sumatera. Skala 1: 100.000. Sheet 1011." Bandung: Pusat Penelitian dan Pengembangan Geologi.

Indradjaya, Agustijanto. 2000. "Strategi Pertahanan Dan Keamanan Pada Kerajaan Sunda (Pada Masa Sri Baduga Maharaja 1482--1521 M).” dalam Cakrawala Arkeologi, editor Fachroel Aziz and Etty Saringendyanti, 112--119. Bandung: Balai Arkeologi Bandung.

Kementerian Pekerjaan Umum. 2010a. "Pola Pengelolaan Sumberdaya Air Wilayah Sungai Mesuji--Tulangbawang." Jakarta: Kementerian Pekerjaan Umum. (https://adoc.pub/pola-pengelolaan-sumber-daya-air-wilayah-sungai-mesujitulan.html). Diakses 1 Juli 2020

—. 2010b. "Pola Pengelolaan Sumberdaya Air Wilayah Sungai Seputih-Sekampung." Jakarta: Kementerian Pekerjaan Umum. (http://sda.pu.go.id/profil/informasi_balai/balai_besar_wilayah_sungai_mesuji__sekampung). Diakses 1 Juli 2020

Koestoro, Lucas Partanda. 2014. “Gajah, Fauna Sumatera Dalam Kisah Sejarah Dan Arkeologi." Sangkhakala 17 (28 April): 83--102.

Laili, Nurul. 2005. "Fungsi Dan Peranan Batu Bergores Dalam Tradisi Megalitik.” dalam Hastaleleka: Kumpulan Karya Mandiri Dalam Kajian Paleoekologi, Arkeologi, Sejarah Kuna, Dan Etnografi, editor Agus Aris Munandar, 33-40. Jatinangor: Alqa Print Jatinangor.

—. 2007. "Permukiman Situs Benteng Majapahit." dalam Permukiman, Lingkungan, Dan Masyarakat. Bandung, editor Supratikno Rahardjo, 81--89. Bandung: Ikatan Ahli Arkeologi Indonesia Komisariat Daerah Jawa Barat dan Banten.

—. 2014. "Keletakan Situs Megalitik Di Kawasan Permukiman Sumberjaya Lampung Barat Dan DAS Sekampung Lampung Timur.” dalam Perkembangan Permukiman Di Lampung Dalam Perspektif Arkeologi, editor Kresno Yulianto, 25- 
39. Bandung: Alqa Print Jatinangor.

Nastiti, Titi Surti. 1996. "Prasasti Kawali.” Jurnal Penelitian Balai Arkeologi Bandung Vol. 4 (November): 19--37.

Poesponegoro, M D, dan Nugroho Notosusanto. 2010. Sejarah Nasional Indonesia.

Editor R P Soejono and R Z Leirissa. 4th Edition. Jakarta: Balai Pustaka.

Poesponegoro, M.D, dan Nugroho Notosusanto. 1993. Sejarah Nasional Indonesia Jilid

2. Jakarta: Balai Pustaka. Editor Bambang Soemadio. 3rd Edition. Jakarta: Balai Pustaka.

Prijono, Sudarti. 2014. “Adaptasi Dan Eksploitasi Terhadap Lingkungan Pada Masa Lampau Di Situs Keramat Teluk Lampung Utara." dalam Perkembangan Permukiman Di Lampung Dalam Perspektif Arkeologi, editor Kresno Yulianto, 7988. Bandung: Alqa Print Jatinangor. (https://doi.org/9789799462824).

Rusyanti. 2011. "Melacak Jejak Permukiman Di Kawali.” dalam Arkeologi: Strategi Adaptasi, Permukiman, Dan Pemanfaatannya, editor Kresno Yulianto, 123--138. Bandung: Alqa Print Jatinangor.

Rusyanti, Ananta Purwoarminta., Agel Vidian Krama., E. Widyastuti., Irwan

Setiawidjaya., D. Saripudin, dan Y. Hardikusmana. 2018. "Lansekap Arkeologi Situs-Situs Di DAS Way Semangka Lampung Barat. Laporan Penelitian.” Bandung: Balai Arkeologi Jawa Barat.

Rusyanti, Agel Vidian Krama., Irwan Setiawidjaya., Y Hardikusmana, dan Acep Adra'i. 2019. “Laporan Penelitian. Lansekap Arkeologi Situs-Situs Di DAS Way Semangka Tanggamus.” Bandung: Balai Arkeologi Jawa Barat.

Rusyanti, Ananta Purwoarminta, Agel Vidian Krama., dan Endang Widyastuti. 2019.

"The Ancient Settlements in the Semangka Fault Line of Liwa, West Lampung, Indonesia." Dalam Advancing Southeast Asian Archaeology: Selected Papers from the Third SEAMEO SPAFA International Conference on Southeast Asian Archaeology, Bangkok, Thailand, 350-58. Bangkok: South East Asian Ministers of Education Organization Project in Archaeology and Fine Arts (SEAMEO SPAFA) Rusyanti, Suwongso Sadewo., Iwan Setiawan., Irwan Setiawidjaya., dan Dayat Hidayat. 2020. "Laporan Penelitian Arkeologi Karakteristik Lingkungan Dan Tembikar

Kumo Di Provinsi Lampung.” Bandung: Balai Arkeologi Jawa Barat.

Rusyanti, Nanang Saptono, dan Endang Widyastuti. 2020. "Melacak Jejak Fitur Parit 
Kuno Masyarakat Lampung: Jejak Migrasi Austronesia Jalur Barat?" dalam Indonesia Rumah Besar Austronesia Dari Masa Prasejarah HIngga Kini, editor Lutfi Yondri and Iwan Hermawan, 127--136. Bandung: Balai Arkeologi Jawa Barat. (https://doi.org/https://doi.org/10.24164/prosiding.v311.15).

Saptono, Nanang. 2001. "Ragam Aktivitas Dan Rancang Bangun Benteng Di Situs Keramat Gemol, Tulangbawang.” dalam Manusia Dan Lingkungan Keberagaman Budaya Dalam Kajian Arkeologi, editor Tony Djubiantono dan M. Ali Fadillah, 26-46. Bandung: Ikatan Ahli Arkeologi Indonesia (IAAI).

—. 2002. "Hubungan Fungsional Situs Benteng Sabut, Benteng Prajurit Putinggelang, Dan Keramat Gemol.” dalam Jelajah Masa Lalu, edtor Agus Aris Munandar, 86--101. Bandung: Ikatan Ahli Arkeologi Indonesia Komsariat Daerah Jawa Barat dan Banten.

- 2003. "Permukiman Situs Benteng Sabut (Bujung Menggalou), Tulangbawang, Lampung.” dalam Mosaik Arkeologi, editor Agus Aris Munandar, 97-110. Jakarta: Ikatan Ahli Arkeologi Indonesia (IAAI).

—. 2004. "Struktur 'Kota' Kuna Gunung Terang, Tulangbawang Lampung." dalam Teknologi Dan Religi Dalam Perspektif Arkeologi, editor Agus Aris Munandar, 42--

54. Bandung: Ikatan Ahli Arkeologi Indonesia (IAAI) Komisariat Daerah Jawa Barat dan Banten.

_. 2007. "Jenjang Permukiman Dan Perkembangan Masyarakat Lampung." dalam Permukiman, Lingkungan, Dan Masyarakat, editor Supratikno Rahardjo, 63-80. Bandung: Ikatan Ahli Arkeologi Indonesia Komisariat Daerah Jawa Barat dan Banten.

—. 2008. "Keletakan Antara Tiyuh Dan Umbul Pada Permukiman Masyarakat Lampung.” dalam Dari Masa Lalu Ke Masa Kini: Kajian Budaya Materi, Tradisi, Dan Pariwisata, editor Wanny Rahardjo Wahyudi, 45--64. Bandung: Alqa Print Jatinangor.

— 2010. "Lebak Lebung Dalam Konteks Peradaban Tinggi Di Tulangbawang." dalam Dari Masa Lalu Ke Masa Kini: Kajian Budaya Materi, Tradisi, Dan Pariwisata, editor Wanny Rahardjo Wahyudi, 5--16. Bandung: Alqa Print Jatinangor.

—. 2013. "Rekayasa Untuk Menghasilkan Pangan Pada Masyarakat Kerajaan Sunda 
Abad Ke-14--16 M.” dalam Widyadwara: Kajian Arkeologis Pangan Dan Papan Warisan Leluhur, editor Agus Aris Munandar, 1--1-18. Bandung: Balai Arkeologi Bandung.

—. 2014. "Pola Perkampungan Dan Mata Pencaharian Masyarakat Lampung." dalam Perkembangan Permukiman Di Lampung Dalam Perspektif Arkeologi, editor Kresno Yulianto, 63-78. Bandung: Alqa Print Jatinangor.

Sieh, Kerry dan Danny Natawidjaja. 2000. "Neotectonics of the Sumatran Fault, Indonesia." Journal of Geophysical Research 105 (B12): 28295. (https://doi.org/10.1029/2000JB900120).

Simanjuntak, T., Adhi A. O., M. Ruli Fauzi, dan Retno Handini. 2017. Berpetualang Ke Gua Harimau. Jakarta: Komunitas Bambu.

Siregar, Sondang M. 2014. “Jejak-Jejak Perkampungan Masa Megalitik Di Situs Padang Ratu Kawasan Danau Ranau Kabupaten Ogan Komering Ulu.” Siddhayatra 19 (No.1, Mei): 18--29.

Sunarningsih, Hartatik, dan Ida Bagus Putu Prajna Yogi. 2020. "Karakteristik Kuta Bataguh Di Kapuas, Kalimantan Tengah.” Berkala Arkeologi 40 (2): 287--308. (https://doi.org/https://doi.org/10.30883/jba.v40i2.590).

Supartoyo, S., dan Eka Tofani Putranto. 2014. Katalog Gempa Bumi Merusak Di Indonesia Tahun 1612--2014. Editor M Hendrasto, Gede Suantika, dan Sri Hidayati .Bandung: Kementerian Energi dan Sumberdaya Mineral Badan Geologi Pusat Vulkanologi dan Mitigasi Bencana Geologi.

Tobing, Binsar D. L. 2004. "Prasasti Hujuy Lańit 919 Śaka (997 Masehi).” Skripsi Sarjana Arkeologi. Depok: Universitas Indonesia.

Triwurjani. 2011. Situs-Situs Megalitik Di DAS Sekampung. Jakarta: Wedatama Widya Sastra.

Utomo, Bambang Budi. 2007. Prasasti-Prasasti Sumatera. Jakarta: Pusat Penelitian dan Pengembangan Arkeologi Nasional.

Wiradnyana, Ketut. 2012. "Indikasi Pembauran Budaya Hoabinh Dan Austronesia Di Pulau Sumatera Bagian Utara.” Sangkhakala XV (No.1. Mei): 99--118.

—. 2015. "Budaya Austronesia Di Indonesia Bagian Barat Dalam Kaitannya Dengan Migrasi Out of Taiwan." Sangkhakala 18 (1): 22-39.

Wiryawan, B. B., Marsden., H A Susanto,. K Mahi., A. M. Ahmad, dan H.Poespitosari 
.1999. Atlas Sumberdaya Wilayah Pesisir Lampug.Bandar Lampung: Kerjasama Pemerintah Daerah Provinsi Lampung dengan Proyek Pesisir Lampung.

Zahorka, Herwig. 2007. The Sunda Kingdoms of West Java: From Tarumanagara to Pakuan Pajajaran with the Royal Cnter of Bogor. Jakarta: Yayasan Cipta Loka Caraka. 